\title{
Euripides in the Poems of Gregory of Nazianzus
}

\begin{abstract}
In Julian's time literature became a main field of cultural war between paganism and Christianity, and Gregory of Nazianzus undertook the task of composing Christian poetry worth of Greek paideia. In spite of the heavy presence of apologetic tradition in his poetry, Gregory also integrated the tragic genre in his poetic work, through the neutralization of tragic language, the treatment of myth as literature, and the portrayal of the suffering Christian as a new tragic hero. Euripides was his favourite author because of his conversational style, his frequent use of didactic sentences, his popularity as a canonical author, and his taste for the pathetic. There are significant poetic precedents in Jewish and Christian tradition for Gregory's enterprise. However, his learned and original reinterpretation of tragic language and themes makes his poetry a central stage of Euripides' reception.
\end{abstract}

\section{Pagan and Christian Debates around Greek Literature in the $4^{\text {th }}$ C. AD}

In his Ecclesiastical History Sozomenus retells the events of the previous $4^{\text {th }}$ c. AD, and he praises the bishop Apollinaris of Laodicea for his poetic work:

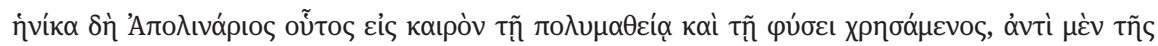

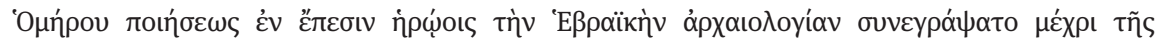

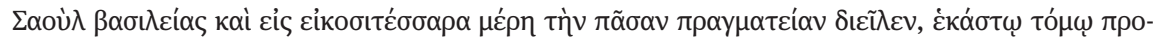

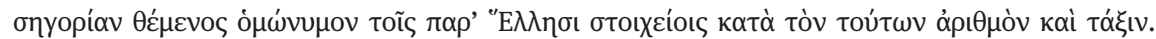

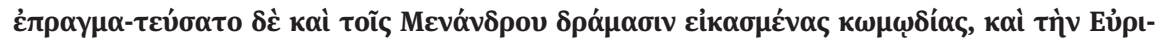

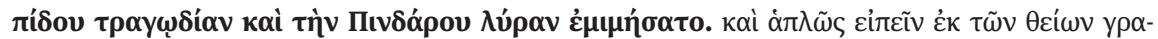

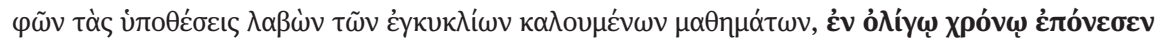

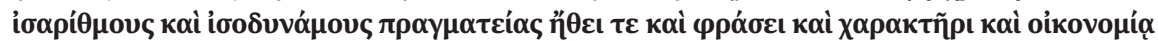

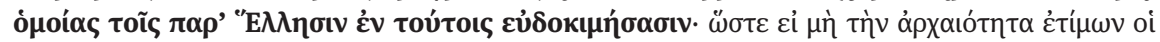

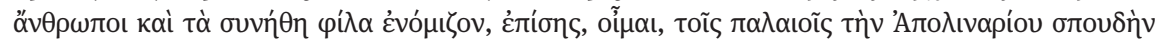

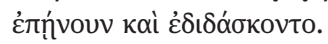

Apollinaris, therefore, employed his great learning and ingenuity in the production of a heroic epic on the antiquities of the Hebrews to the reign of Saul, as a substitute for the poem of Homer. He divided this work into twenty-four parts, to each of which he appended the name of one of the letters of the Greek alphabet, according to their number and order. He also wrote comedies in imitation of Menander, tragedies resembling those of Euripides, and odes on the model of Pindar. In short, taking themes of the entire circle of knowledge from the Scriptures, he produced within a very brief space of time a set of works which in manner, expression, character, and arrangement are well approved as similar to the Greek literatures and which were equal in number and in force. Were it not for the extreme partiality with which the pro- 
ductions of antiquity are regarded, I doubt not but that the writings of Apollinaris would be held in as much estimation as those of the ancients. (Soz. Hist. Eccl. 5,18,3-5, tr. Hartranft)

Apollinaris would have demonstrated the ability of Christians to compose poetry of high quality in each of the classical genres with new contents. Though nothing of his production has been preserved, we may be sure that Sozomenus is exaggerating the literary capacities of Christian poets in the $4^{\text {th }} \mathrm{c}$. AD in his idealized portrait. However, the pagan matches for Apollinaris are revealing: Euripides is the representative model for tragedy, just as Homer for epic and Menander for comedy. ${ }^{1}$

Sozomenus is taking Apollinaris as an example of the Christian reaction against Emperor Julian's prohibition in 362 that Christians taught the classics. This startling edict was not a Christian invention, no matter how much they may have overreacted at the time and after Julian's death. The spirit of this law is well described by the Emperor himself:

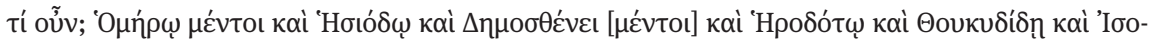

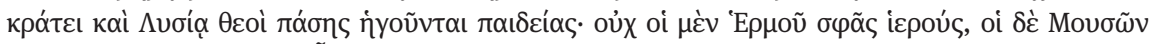

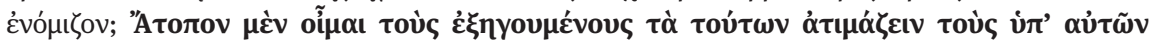

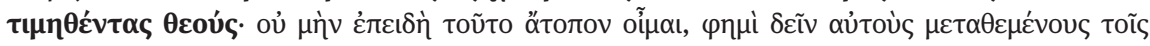

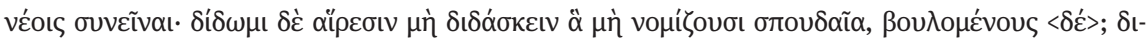

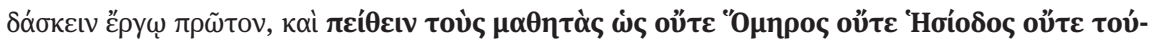

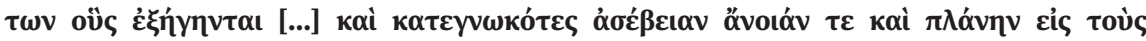

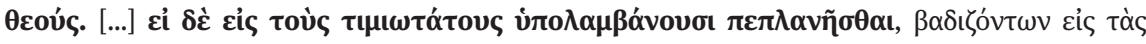

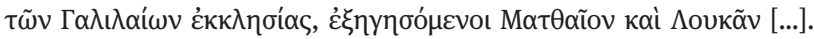

Was it not the gods who revealed all their learning to Homer, Hesiod, Demosthenes, Herodotus, Thucydides, Isocrates and Lysias? Did not these men think that they were consecrated, some to Hermes, others to the Muses? I think it is absurd that men who expound the works of these writers should dishonour the gods whom they used to honour. Yet, though I think this absurd, I do not say that they ought to change their opinions and then instruct the young. But I give them this choice; either not to teach what they do not think admirable, or, if they wish to teach, let them first really persuade their pupils that neither Homer nor Hesiod nor any of these writers whom they expound and have declared to be guilty of impiety, folly and error in regard to the gods, is such as they declare. [...] If, however, they think that those writers were in error with respect to the most honoured gods, then let them betake themselves to the churches of the Galilaeans to expound Matthew and Luke! (Iul. ep. 61c, 423 A1-B4. D2-5, tr. Wright)

The fact that prose is preponderating over poetry in Julian's passage is probably due to the interests of Julian and his politically focused circles, but this should not make us think that poetry was not originally involved in this quarrel, as shown by the two first authors in his canonical list, Homer and Hesiod. What is at stake in the $4^{\text {th }} \mathrm{c}$. AD is not which authors are canonical or representative of each genre, which may vary

1 This triad is almost canonical in Late Antiquity and shared by pagans and Christians (e.g. Dio Chrys. or. 18,7). Cf. Easterling and Miles 1999, 105. 
rapidly according to fashions or tastes. Rather, it is the cultural war between increasingly triumphant but also increasingly diverse Christians, and the different circles of resistant paganism, which reached a highpoint in the struggle around the legitimacy of Christians to read and teach classical authors - a cultural war in which the leading figures are Julian and Gregory of Nazianzus. Julian's forbidding decree reveals the crucial role of classical literature in the definition of religious, ideological, and cultural identities. Besides, within the ranks of the Christians themselves the use of Greek literature (even stripped of "doctrinal” contents), had both critics and defenders, and the latter had to specify how this literature should be read and taught, as shown by Basilius' famous work To the young men: how they should use accounts from the Greeks. ${ }^{2}$ It was a very delicate matter which demanded great culture, subtlety, and imagination.

Previous chapters in this volume have treated the diverse uses of Euripides in Philo and early Christian authors in apologetic and even exegetic or philosophical contexts, which are concentrated on direct or indirect quoting, and, occasionally, paraphrasing. However, from the $4^{\text {th }} \mathrm{c}$. AD onwards some prominent Christians began to cultivate different genres of poetry, and Euripides, as other Greek poets, began to be also a source of inspiration and imitation. As Sozomenus' text shows, formal mimesis of classical Greek authors was proudly acknowledged, like in the increasingly popular Homeric centos relating to the Biblical episodes, in Synesius of Cyrene's adaptation of Greek hymnic traditions to Christian cult, or in original combinations of different models, like the poems of Gregory of Nazianzus. ${ }^{3}$ Writing poetry in any of these forms was a conscious effort to incorporate Christianity into the Greek paideia and vice versa. Traditionally the transition in meters and themes from classic to Byzantine poetry has been attributed to these well-known poets, above all to the towering figure of Gregory of Nazianzus, who paved the way for later literary standards.

Until a couple of decades ago, the only Christian precedent were a few sporadic hymnic passages of probable liturgical use. However, the publication of the different pagan and Christian texts of the so-called Bodmer Papyri, which originate from a collection of books in a Pachomian monastery, have proven that in the early $4^{\text {th }} \mathrm{c}$. AD poetry was already being composed by Christians, without any trace of the sharp division between pagan and Christian which is characteristic of the texts around Juli-

2 On pagan-Christian debates on the interpretation of texts, cf. generally Kahlos 2012; particularly on Gregory vs. Julian, see Elm 2012.

3 The first preserved Christian hexametric cento is Ps-Apollinaris' Paraphrasis of the Psalms $\left(4^{\text {th }} \mathrm{c}\right.$. AD), followed by the Bishop Patricius and Empress Eudocia in the following decades. Their metre imposes a limited presence of echoes from tragedy. Likewise, Synesius' Hymns, though classisizing, have a different register and meter. As for Western authors, there is no trace of a direct reading of the Greek tragedies by Latin Christian poets and the presence of Euripidean myths in their works is clearly mediated by Seneca and Ovid. 
an's time. ${ }^{4}$ In Gregory's poetry, just as in his discourses and letters, there are constant references in apologetic tone to "their" mythoi vs. "our" logoi, to alien (xenoi) arguments referring to Greek "pagan" theories and myths. Instead, these papyri witness a coexistence of pagan and Christian literature without a clear concern about religious affiliation, much in the spirit of what most recent scholarship has theorized about Nonnus of Pannopolis. ${ }^{5}$ Tragedy, and particularly Euripides, is much present in these poetic circles. The poem known as the Barcelona Alcestis, one of the few Latin pieces from the collection of Bodmer papyri, depends primarily on the Euripidean piece. It is a pagan work, but was copied and read in the same school in which Christian poets were trained to compose ethopoietic declamations, just as a short iambic poem on "what Cain would have said" after killing Abel. Compositions of this kind (ethopoeia) were a typical rhetorical exercise of which papyri have furnished numerous examples, and of course tragic monologues were a primary model for them, especially when, as is the case in the Cain poem, it is written in iambic trimeter. ${ }^{6}$

Granted, one cannot directly extrapolate the situation in Egypt, be it in the $4^{\text {th }}$ or $5^{\text {th }}$ c. $\mathrm{AD}$, to Cappadocia, but the Bodmer papyri help to draw a more accurate and nuanced portrait of Gregory's pioneering role in the establishment of Christian poetry. He himself addresses other (rival) poets in several passages of his poem On his own verses (carm. 2,1,39): even after accounting for the topoi of iambic invective tradition, these references point to contemporary Christian poets. ${ }^{7}$ The papyri precisely demonstrate that previous Christian generations had been composing classicizing poetry. This Christian tradition must be added to the previous Jewish Hellenistic poets which were used, transmitted, and quoted by Christians, like Pseudo-Phocylides and Ezechiel the Tragedian, who also integrated Euripides in a non-apologetic effort of Hellenization of Biblical tradition. ${ }^{8}$ However, Gregory remains the first witness of the combination of this Hellenizing tradition of Christian poetry, which coexists in neutral juxtaposition with Greek pagan literature, and the apologetic tradition of drawing a sharp religious boundary between two opposed and irreconcilable sides. He does indeed criticize pagan poets; and, at the same time, he imitates them. Euripides' reception is paradigmatic of how this combination implied a new, different equilibrium that Gregory struggled to attain with no little success. ${ }^{9}$

4 On the Bodmer collection, see Robinson 2011.

5 On Nonnus, see Thomas Schmitz in this volume.

6 On the Christian ethopoietic poems of the Codex Visionum, cf. Agosti 2005 in a collective volume on ethopoeia.

7 Carm. 2,1,39, 1-4, 69-77. Cf. Milovanovic-Barham 1997, and Hawkins 2014, 142-83.

8 For passages of Pseudo-Phocylides with clear Euripidean parallels, see Van der Horst 1978, 116, 148, 167, 214, 241, 244. For Attic tragedy in Ezechiel, see Vogt 1994.

9 On Gregory's critique of pagan poets, see Prudhomme 2009. On the presence and absence of apologetics in his poetry, see Herrero de Jáuregui 2011 (with the reply of Roessli 2014). 


\section{Gregory as a Poet}

Editions, translations, and commentaries of particular poems of Gregory have been slowly emerging in the last decades. Yet critical editions are still a minor part of the more than 18.000 verses that are collected in Migne's Patrologia Graeca, which reproduces the unfinished and disorderly $18^{\text {th }} \mathrm{c}$. AD edition of his works by Maurine monks. ${ }^{10}$ The two iambic poems from which most Euripidean references will be excerpted have been edited recently and are among the best-known ones: On His Own Life (carm. 2,1,11) and On Virtue (carm. 1,2,10). ${ }^{11}$ Most studies make often a general reference to Gregory's frequent use of classical authors, especially Homer, and parallels with poets like Archilochus, Sappho, or Callimachus in specific verses have been duly noted as a clear sign of his outstanding learning. ${ }^{12}$ Regarding tragedy, Paul Stoppel in 1881 made a specific study on his imitation of scenic poets that, however, received this severe criticism from Wilamowitz: "Für Gregor von Nazianz trägt Stoppel viel zusammen, was teils ganz nichtig ist, teils auf die Benutzung der Lexica weist, die bei Gregor sehr deutlich ist. Sicher kennt er nur Eur. Hec. Or. Phoen. Med. Andr. Alc., wenn auch nur so viel."13

As Bernard Wyss showed, Wilamowitz was wrong in supposing that Gregory used lexica, for it is exactly the contrary: Byzantine lexicographers often used Gregory's poetry to investigate the meaning of early poetic terms. Besides, the "nur" is not only anachronistic, but quite unfairly judgmental, and at least Bacchae should be added to the list of Euripidean tragedies (apart from Sophocles' Ajax and Oedipus Rex) known by the Cappadocian Father. ${ }^{14}$ However, Wilamowitz was right in the first part of his criticism that often the parallels that are alleged are "nichtig", i.e.

10 The Maurine edition was lost during the French Revolution and was recovered by D. A. B. Caillau, whose edition (1840) is reproduced by Migne. The poems follow this numbering since no edition has replaced them. Translations from the poems are mine except otherwise indicated. I will not tackle here the contested issue of the authorship and dating of Christus Patiens (see the contribution of Lena Krauss in this volume).

11 Jungck 1974 edited On His Own Life (carm. 2,1,11), Gregory’s longest poem (1949 lines); Crimi and Kertsch 1995 edited and commented On Virtue (carm. 1,2,10), which has 998 lines. Several other single poems have also been edited and commented (among those referred in this paper, Bernardi 2004 on carm. 2,1,1-11; Simelidis 2009 on carm. 1,2,17; 2,1,10; 2,1,19; 2,1,32; Meier 1989 on carm. 2,1,12; Tringali 2012 on carm. 2,1,13).

12 Prudhomme 2006 in her thesis has thoroughly researched important literary aspects of Gregory's poetic work underlining his reception of classical authors; Demoen 1996 collected his mythical exempla mostly taken from Homer and Hesiod; Moreschini and Sykes 1997 note the frequent parallels with epic poetry; see Kambylis 1982, Simelidis 2009, Hawkins 2014, 142-83, and Basso 2015 for his poetic relation to Archilochus and Callimachus; Cataudella 1927 and Koster 1964 for his use of Sappho. 13 Stoppel 1882; Wilamowitz 1889, 202.

14 Wyss 1949, 192, with n. 42. Wyss 1983, 846 lays out the clearest traces of Sophocles' Oedipus Rex, Ajax, and perhaps Antigone. He finds no direct trace of Aeschylus, while the largest quantity of tragic echoes is, as expected, Euripidean: Wyss' list of undoubtful parallels in the Gregorian poetic corpus is a secure reference. 
they prove little beyond the obvious reality that his poetry, as his oratory, imitates classical literature. We should, therefore, avoid falling again into the compulsive or occasional gathering of parallels, and rather attempt to categorize the levels and intentions of Gregory's reception of tragedy, particularly of Euripides.

Clearly some of the following considerations might be valid for the Christian reception of tragedy as a whole and even of all classical poets. However, tragedy had the specificity of having been performed in a most prestigious past, which still lingered in the collective memory, and being still reperformed in the theatre, even if the actual performances consisted mostly in recitations of parts, or mute versions in mimes and pantomimes. ${ }^{15}$ Christian condemnation of theatrical spectacles only partially affected the prestige of tragedy, for it was also an elevate and respected literary genre that was often read, excerpted, and quoted as a mark of general culture. On the other hand, it was never (unlike Homer or Hesiod) religious poetry used by pagan circles as sacred text used in ritual enactments or allegorical interpretations. Finally, among the three tragedians, Euripides is particularly relevant in this respect, not only because of his popularity as a source of gnomic wisdom, but also, as we shall see at the end of this chapter, because his flexible linguistic register and the idiosyncratic thematic orientation of his tragedies made him especially profitable for Christian poetry. ${ }^{16}$

\section{Explicit and Implicit References}

Gregory's preferential attachment to Euripides is clear, but it is not explicit; it must be deduced from his references. In all his work, Gregory quotes him by name only twice: once in a letter with a rhetorical quotation of gnomic tone ("as Euripides says, the worst of the daemons is the love of glory"); ${ }^{17}$ the second time is in the iambic poem On Virtue (carm. 1,2,10), in which he reviews quite disdainfully pagan doctrines, which he deems weaker in comparison with Christian ones, although sometimes he admits glimpses of truth in some pagans. The passage deserves being examined in context, since it is preceded by an anecdote around two Euripidean verses:

15 See the contribution of Martin Hose in this volume, p. 32-38.

16 See Easterling and Miles 1999 for tragedy in Late Antiquity, and Funke 1965/66 for Euripides' reception in early Christianity (see also the chapters by Francesco Massa and Sébastien Morlet in this volume).

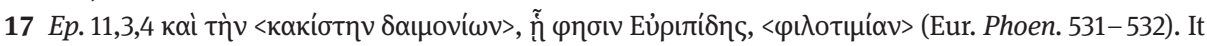
is a letter to Gregory of Nyssa in which he is explicitly imitating the resounding style of rhetoricians and therefore he indulges in pedantic name-dropping which otherwise he avoids. Easterling and Miles 1999, 103, explain the quotation as an example of Greogry's resorting to his common bond of paideia with his friend to win him over. Cf. Crimi 1981 on theatrical quotations in Gregory's epistolary (p. 45 on this passage). 


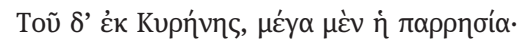

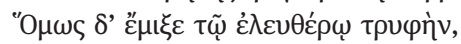

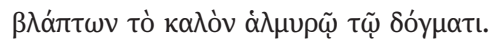

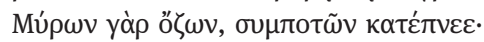

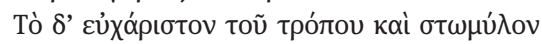

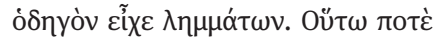

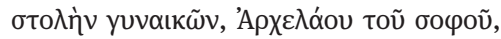

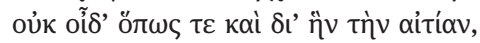

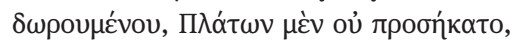

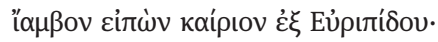

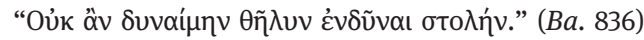

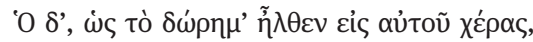

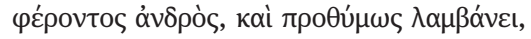

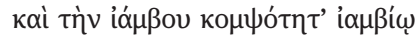

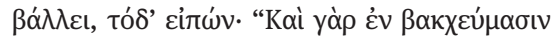

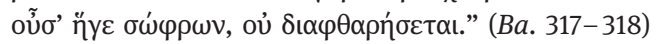

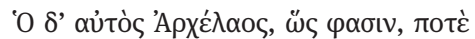

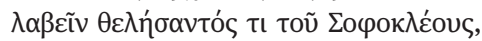

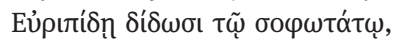

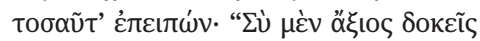

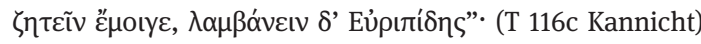

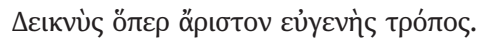

The man from Cyrene (scil. Aristippus) had something great, his free speech. But he mixed with this freedom the lassitude, polluting the good with a stringent doctrine. He was perfumed with oil and his banquet companions inspired this, and his agreeable manners and his astuteness opened him the way to make profit. So once, when Archelaus wanted to give a piece of cloth to the wise men, I don't know how or for which reason, Plato did not accept it, saying a convenient iambic line from Euripides: "I could not put on a feminine dress" (Ba. 836). The other, as the gift went into his hands when somebody gave it to him, takes it enthusiastically and answered back the iambic trap with an iambus, saying these: "for even in the Bacchic feasts she who is moderate will not be corrupted" (Ba. 317-318). The same Archelaus, as they say, once that Sophocles wanted to take something, gave it to Euripides, adding this much: "you are worth of asking me, but Euripides is worth taking" (T 116c Kannicht). Thus he showed that the best thing is a noble behaviour. (carm. 1,2,10, 324-346) $)^{18}$

Gregory mistakenly speaks of the Macedonian king Archelaus as protagonist of a rift between Plato and Aristippus, each one quoting a verse from the Bacchae, while the other sources for the anecdote speak of the tyrant Dionysius, who is of course more plausible as a host of Plato. ${ }^{19}$ He then goes on to tell another anecdote in which Archelaus expresses his preference for Euripides over Sophocles - a story Plutarch tells without naming Sophocles. Since the only link between the two anecdotes is Archelaus, on the one hand, and Euripides as poet of the lines of the Bacchae, on the other, it would seem that Gregory has indeed made an (unconscious?) effort to put

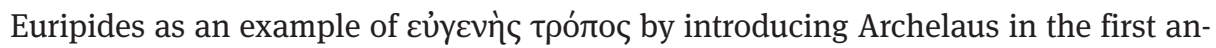

18 Cf. Crimi and Kertsch 1995, 259.

19 Cf. Stob. 3,267,38; Diog. Laert. 2,78. 
ecdote, so that the second one comes more naturally. Making such a tour de force to praise Euripides in a list of Cynic philosophers (immmediately afterwards he praises Aristides for his honesty) seems telling regarding Gregory's predilection for him. The conclusion of this paper will come back to the possible reasons for such predilection.

After this unique case of explicit mention, there are a few other cases in which there might be an implicit allusion to Euripides. In the same poem On Virtue (carm. 1,2,10), some lines after the praising of Euripides, Gregory opens a section with criticism on the moral advices of "old books" and accumulates three Euripidean sentences, of which he disapproves:

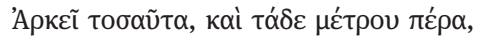

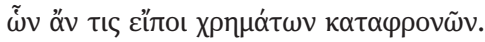

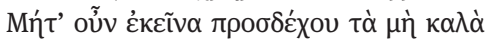

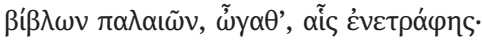

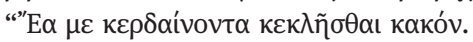

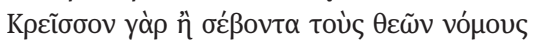

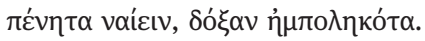

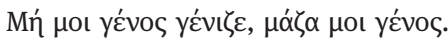

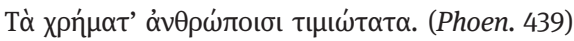

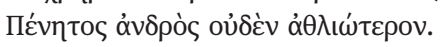

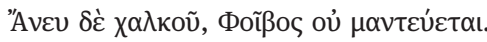

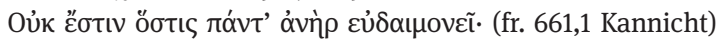

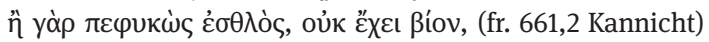

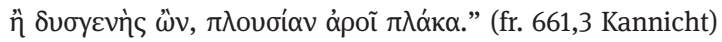

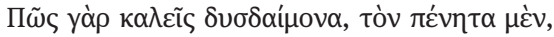

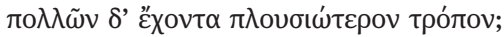

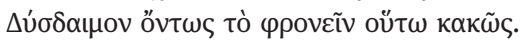

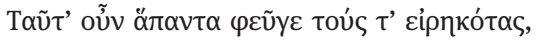

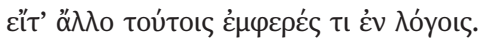

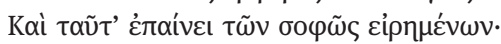

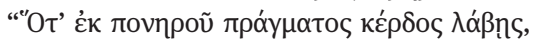

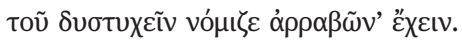

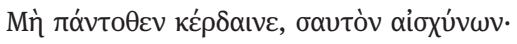

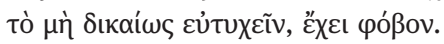

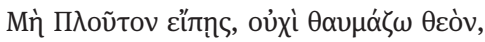

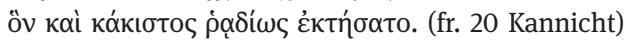

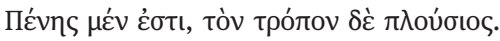

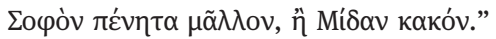

These things are enough, do not go beyond the measure that a man despising wealth should respect. So do not receive those unworthy teachings of ancient books from which, my good man, you were bred: "let me take profit and be called evil; better this than to respect the laws of the gods and find yourself poor, though with good reputation. Do not show your lineage, my lineage is food. Wealth is for men the most honoured thing (Phoen. 439). There is nothing more unhappy than a poor man. Without money, Phoebus does not offer oracles. There is no man who is happy everywhere: either he is noble by birth and has no means for living, or he is of humble origin and labors a fertile land (fr. 661 Kannicht)". How can you call unhappy the poor, who has a much richer behavior than many? It is indeed unhappy to think so stupidly. Reject, then, all these precepts, he who enunciated them and whatever similar there is in those 
speeches. And approve those said wisely: "when you profit from a bad enterprise, consider that you are taking a bond for misfortune. Do not profit from everywhere, have respect for yourself. Well being from injustice brings fear. Do not invoke Wealth: I do not admire a god who is easily acquired by the worst man (fr. 20 Kannicht). He is poor, but wealthy in behavior. Better a poor wise man than a bad Midas." (carm. 1,2,10, 379-392) ${ }^{20}$

Taking into account that some lines later (393-410) he will criticize Theognis and Homer (mistaking him for Hesiod probably due to a slip of the mind), it is possible that the rhetorical question in 379-380 ("how can you call unhappy...?"), would be addressed to Euripides. But it seems more probable that the plural "flee those who say this" (382) indicates rather a generalizing multiple addressee: either Gregory refers to those who think in this way like Polynices, the character speaking in Phoenicians 439 (quoted in line 373), or to tragedians or poets in general, or even to the gnomologic collections in which many lines from Euripides and also other authors were collected, and which are the most probable source for this passage. ${ }^{21}$ The generalising plural seems to mitigate the charge of immorality as a specific accusation on Euripides, and therefore does not diminish the explicit praise that has been made some lines before.

The other case in which Gregory has been thought to refer specifically to Euripides is in an ethopoietic poem in hexameters addressed to a father, Vitalianus, from his sons with whom he has quarrelled (carm. 2,2,3). They would speak through the poet's voice:

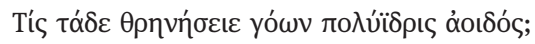

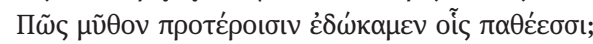

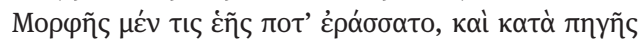

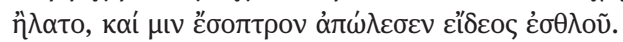

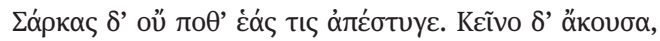

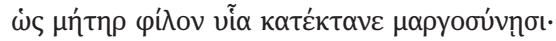

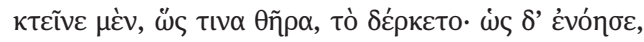

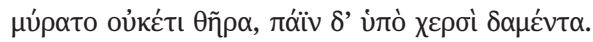

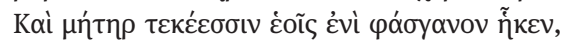

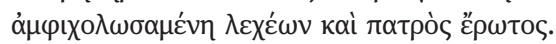

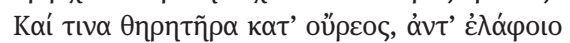

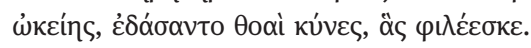

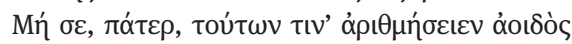

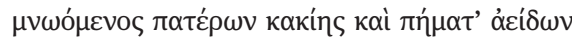

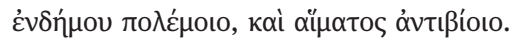

What singer, experienced in lamentations, could bemoan our situation?

How have we provided a subject to the ancients with our sufferings?

20 Cf. Crimi and Kertsch 1995, 266-268.

21 Wyss 1983, 848; Azzarà 2003, 57-59 proposes that these strings of citations, of which there are numerous parallels, may come from a "plurality of gnomological sources". Cf. Crimi and Kertsch 1995, 264-267, and Kannicht's apparatus for other sources transmitting these fragments (Eur. fr. 661 is very similar to fr. 285 Kannicht). 
Once one that was in love with his own image jumped into a fountain And thus the reflection of his own excellent figured killed him.

But nobody has ever rejected his own flesh. I have heard the following.

A mother finished her beloved son off in a fit of insanity:

in her eyes she did kill an animal; yet when she came to her senses again,

she no longer mourned an animal, but her child, killed by her hand.

Another mother thrust a sword into her own children,

in a blind rage over her marriage and their father's adultery.

In the shape of a nimble hart, a hunter in the mountains

was lacerated by his swift dogs, whom he dearly loved.

Please avoid, father, a singer's reciting you in this list

when he recalls wicked fathers and sings about the misery

of civil wars and of hostility between blood relations.

(carm. 2,2,3, 50-62, Demoen's translation, modified)

There is an obvious reference to the poet himself as aoidos, which is corroborated by the fact that later in the same poem, Gregory compares himself with Echo and Or-

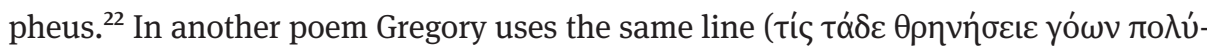

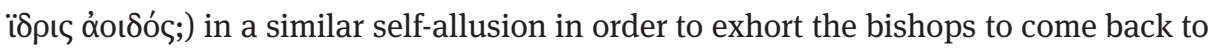
a pure life. ${ }^{23}$ However, since in this paragraph there is a clear accumulation of tragic plots paradigmatic of mothers killing sons (Agaue and Medea), Demoen has hypothesized that Gregory might be referring to Euripides, since the myths that this aoidos would sing could be easily ascribed to his tragedies - even Actaeon, whose myth is alluded in the Bacchae as a negative paradigm, underlining that he was destroyed

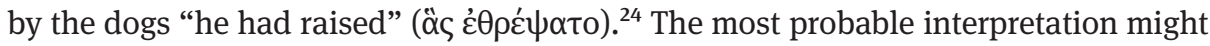
well be in a middle ground: Gregory is doubtless referring to himself as the singer who would add to this sequence a new story of tragic and murderous pathos; but it is nevertheless telling that he recollects several arguments that, all together, become recognizably Euripidean: in a way, he is postulating himself as the actual polyidris singer and comparing himself to the tragedian as a classical model.

These are the only instances in which Gregory, explicitly or implicitly, individuates Euripides as author. In a few other occasions, he alludes to "tragedy" in a generic way in his poems. In the poem On Virtue, slightly earlier than the aforementioned praise of Euripides, he criticizes the ostentation of poverty among Cynic philosophers, and he alluded to a well-known anecdote in which Diogenes uses metaphorically a Euripidean line to refuse a cake which was among olives: ${ }^{25}$

22 Cf. carm. 2,2,3, 198-215.

23 Cf. carm. 2,1,13, 195. It comes as a conclusion after telling several episodes from the Old Testament.

24 Eur. Ba. 337-340. Cf. Demoen 1996, 87. Tringali 2012, 114 is sceptical since she would expect $\tau \rho \alpha-$

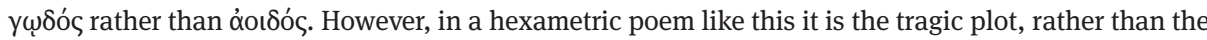
dramatic form, the relevant feature of the song of the poet, so Euripides could be called óotós. 25 The anecdote is told by Diogenes Laertius 6,55. Crimi 2014 makes a detailed exegesis of this passage. 
$\Delta \eta \lambda$ oṽ

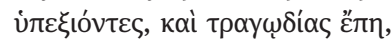

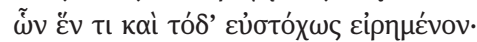

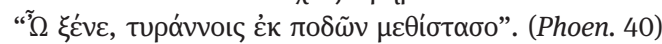

(Sobriety) is shown by the pieces of bread that leave their place to the sesame loaves, and the lines of the tragedy, one of which says shrewdly: "oh, stranger, get out from the way of kings". (Phoen. 40) (carm. 1,2,10, 276-281)

Later still in the same poem, he refers to some gnomic lines from different tragedies; after Chares he quotes a well-known line by Euripides: ${ }^{26}$

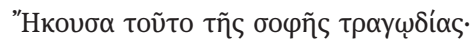

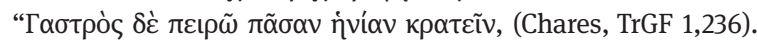

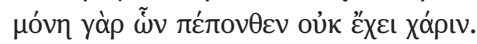

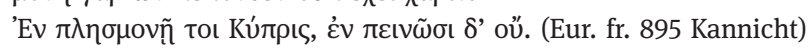

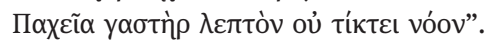

I heard this from the wise tragedy. "Try to dominate the reins of the stomach (Chares, $\operatorname{TrGF}$ 1,236 ), it is the only one who does not prove gratitude for what he receives. Cypris is in satiety, not in hungry men (Eur. fr. 895 Kannicht). Greasy stomach does not produce acute thoughts”. (carm. 1,2,10, 585-589)

Like the previous mention, the quotation seems to come from some anthology of gnomai, but nevertheless he says that it is "wise tragedy", without any note of irony. These allusions show that taking scattered lines from gnomologies does not imply forgetting their origin in tragedy. On the contrary, it becomes a way to integrate this genre as part of the great stream of popular wisdom.

There are still two other explicit mentions of tragedy, referring to the style, rather than to the content. One is from the poem On His Own life, in which he criticizes his enemies:

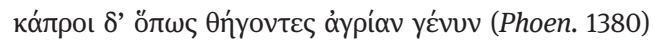

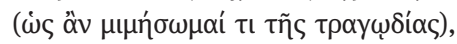

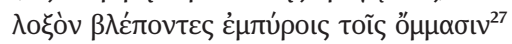

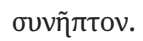

"Like boars which sharpen their fierce teeth" (Phoen. 1380) (to imitate a passage of tragedy), looking obliquely with fiery eyes, they went against each other. (carm. 2,1,11, 1804-1807).

In a very similar context, the last acknowledged quotation from tragedy takes place in an autobiographical poem against his Christian enemies. He imitates the tragic style with a touch of self-irony, when he speaks about his unfair mistreatments in

26 This Euripidean line is quoted by several other sources (cf. Kannicht's apparatus ad fr. 895). 27 Bernardi 2004, 201 ad loc suggests that this line should be restored in the text of Euripides, which is not right: it comes after the parenthesis, and in any case Gregory does not follow slavishly Euripides but uses him as inspiration for his own creation. 
Constantinople using the same locution than Sophoclean Oedipus lamenting how the city he once saved is now mistreating him unfairly:

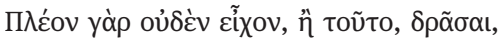

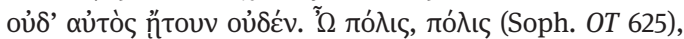

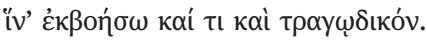

They could not do more than that, and I did not ask for anything: "oh, city, city" (Soph. OT 625), so that I will cry yet something tragic. $(\text { carm. } 2,1,12,135)^{28}$

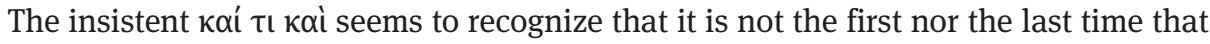
he will use tragic expressions. But this one is so patent that he feels forced to make it explicit.

It seems significant that all the explicit references to tragedy in the whole poetic corpus except this last one refer to Euripides. On the one hand, they clearly corroborate Gregory's preference for him, be them either from gnomologies or from direct reading of (parts of) his plays in each case. On the other hand, they are representative enough to realize that Gregory acknowledges his relation to tragedy in three lev-

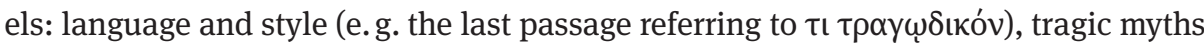
(e.g. the poem about Vitalianus and his sons, carm. 2,2,3), and tragic ethics (e.g. those in the poem On Virtue, carm. 1,2,10). The rest of this chapter will explore these three levels of reception of Euripides in this order.

\section{Style}

It has been widely recognized since Stoppel that Gregory takes much inspiration from Greek tragedy, especially from Euripides, mostly in his iambic lines, just as in hexameters he uses Homeric style. ${ }^{29}$ Recently Juliette Prudhomme has thrown further light on how Gregory treats tragic nouns, adjectives, verbs, and particles. The materials are overwhelming and disparate, so to avoid arbitrary accumulation of parallels from everywhere, it is preferable to focus on a single representative work: Jungck in his 1974 edition of the iambic poem On His Own Life offers in the index a list of 62 parallels with Euripides (for 17 of Sophocles and 13 of Aeschylus). In this list, there are a couple of paradigmatically Euripidean expressions literally reproduced, which amounts to a quotation that should be perceived as such: when Gregory says he seemed to see "two suns and two Romes" he is clearly alluding to Pentheus' vision in the Bacchae

28 Cf. Meier 1989, 90 in his commented edition of the poem.

29 Stoppel 1881 spots 33 undoubtful borrowings from Euripides, most of which come from the Phoenicians and Orestes: cf. Funke 1965/66, 272; Wyss 1983, 847-848. 
of "two suns and two Thebes". ${ }^{30}$ A more dubious allusion could be spotted when he

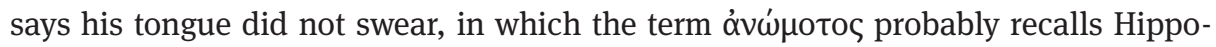
lytus' utterance (with identical sedes metrica): is it a quotation from Euripides or from a proverbial expression? ${ }^{31}$

However, the rest of sixty parallels are too slight to think that there is any direct reference to Euripides, even to a trained and erudite ear. Rather, most of them are examples of what Richard Rutherford has denominated the stylistic koine of tragedy. ${ }^{32}$ Terms and expressions to convey the idea, for instance, of "fleeing the dis-

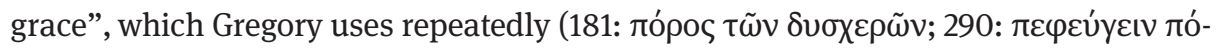
vous; 394: $\alpha \operatorname{\pi } \alpha \lambda \lambda \alpha y \eta \dot{v} \kappa \alpha \kappa \tilde{\omega} v)$ are more than an elevate linguistic register; they are typically tragic, even if they are not explicitly linked to a particular play. It is no wonder that very similar formulations can be found in preserved Euripidean tragedies. ${ }^{33}$ As it is usual in such mimetic processes, the greatest number of parallels is in the final clause of the line. As Stoppel and Prudhomme demonstrated, in the lexical level Gregory takes up a good number of Euripidean neologisms, which are thus incorporated to Christian poetry. ${ }^{34}$ Likewise, stylistic resources like specific interjections, the "exclamative genitive", polyptoton, asyndeton, or stichomythia, are typical from tragedy and profusely used by Gregory to achieve tragic tone. ${ }^{35}$ Two poems are composed in dramatized form.

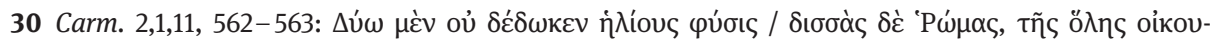

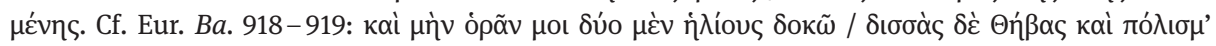

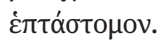

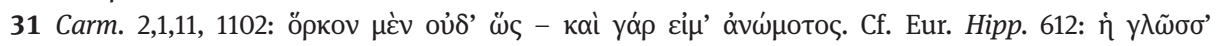

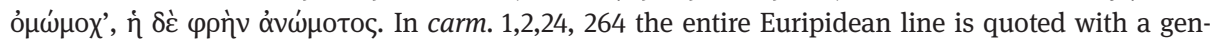
eralizing "many say". However, see Nesselrath in this volume on Themistius' quotation of the line (In Anal. post. 23,25 Wallies), specifically ascribed to Euripides. A similar case: in Kannicht's apparatus to

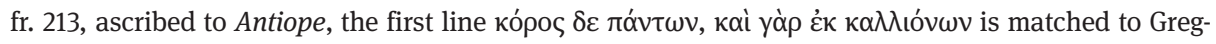

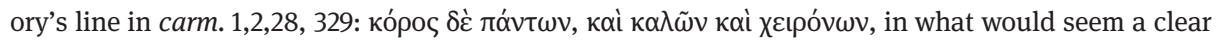
citation, if it were not understood as a proverbial expression.

32 Rutherford 2012, 399, with n. 1: "certain common phrases which come close to tragic formulae:

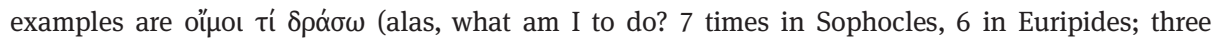

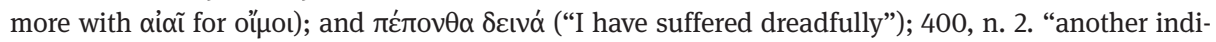
cation that there was to some extent a tragic koine is the frequency of contested ascriptions in ancient sources".

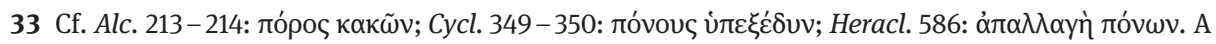
famous parody of tragic koine is A. E. Housman's "Fragment of a Greek Tragedy".

34 Stoppel 1889; Prudhomme 2006, 145-146, 196-197, 490. See Simelidis 2009 on the expression ßíov ع̌ $\lambda \kappa \varepsilon เ v$, which was only found in Euripides' Orestes (206-207) and Phoenicians (1535): Gregory uses it in carm. 2,1,32, 4, and after him others like Gregory Thaumaturgus, Nonnus, and Synesius (it could also be a late Antique trend rather than direct influence).

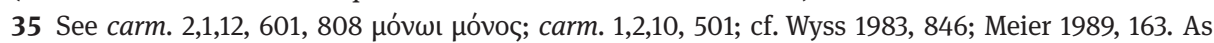
Rutherford 2012, 55, 77 shows, this kind of effects may spring from Gorgianic influence, but they were incorporated to the tragic koine. Wyss 1983, 846 regards the two dramatized poems as inspired by tragic style, though he recognizes that they also imitate other genres: the Socratic dialogue in carm. 1,2,24, and synkrisis in carm. 1,2,8. 
Now this stylistic level aims to accomplish the neutralization of Greek tragedy as an essentially "pagan" genre through the recycling and reusing of lines, formulas, or terms that are used in tragedy, and that the audience should recognize not so much as belonging to a specific piece or a particular author as to the tragic genre. In this way the kind of pathetic elevate register associated with tragedy is deprived of its ideological pagan connotations, and, in contrast with the traditional trend of Christian boasting of a purposefully plain and inartificial language, it will become incorporated to the new Christian paideia.

However, this process is not straightforward, for many of the parallels with tragedy do not show a particularly tragic register. In the first place, one must distinguish between specifically tragic resonances and those expressions that in Late Antiquity were popularized sentences, poetic gnomai that circulated wisely independently of their presence in tragedy (or comedy). Sometimes the tragic or comic author would be the original coiner of the sentence, sometimes a character in a dramatic piece would be echoing a popular expression that already existed. In whichever case (as the large presence of Euripidean and Menandrean lines in the Corpus Paremiographum Graecorum shows), a significant number of the apparent parallels with tragedy could be perceived as merely proverbial sentences, since the iambic trimeter is the most typical scansion of popular expressions. ${ }^{36}$ Even two apparently literal quotations could perhaps resound more as a coined proverb than as a Euripidean allusion: "my tongue has sworn but not my conscience" and "richness is for man the most honoured good", which have been cited above as Euripidean references, could perhaps remind the poet and his audience more of a proverbial expression than of Hippolytus and Polynices respectively. ${ }^{37}$ Another paradigmatic instance is in the poem On His Own Life (carm. 2,1,11), where he calls his own father "a measure of

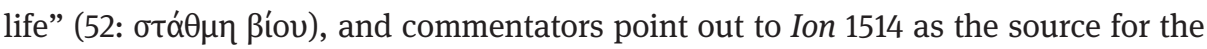
expression. ${ }^{38}$ However, since Aryeh Finkelberg has recently shown that this is probably an expression coined by Heraclitus, that was later taken falsely as a title of his work, the doubt remains whether Gregory took it from Euripides, from Heraclitus, from both, or just from a general reminiscence of an elevate expression to mean "life". 39

Besides, iambic trimetre was considered the meter most similar to spoken language, so the recycling of expressions from tragedy that do not carry a tragic register

36 Funke 1965/66, 272-274 shows Euripides' popularity among Christians as a source of wisdom sayings. On the iambic form of gnomai, see Most 2003 (esp. 151-152). Simelidis 2009, 197 on the specific case of the phrase "golden wings": carm. 2,1,19, 44 is parallel to Eur. fr. 911 Kannicht, Ba. 372, but to many other works, too.

37 See notes 23 and 34 respectively. Cf. Prudhomme 2006, 218-222 on a passage in carm. 2,1,39, 54-59, in which Gregory compares himself to an old swan: it seems inspired by the choir of Euripides' Heracles (691-694), but this may have become a literary topos by Gregory's time.

38 See Jungck 1974 and Bernardi 2004 ad loc.

39 See Finkelberg 2017, 31 n. 46 (who acknowledges the intuition of Patin 1892, 4 n.3). 
is only natural. As Proudhomme has noted, it is often difficult to differentiate poetic and prosaic register since, as ancient critics remarked, often iambic trimetres sounded just like versified prose. ${ }^{40}$ For instance the audience would surely not recognize as resounding with tragic or even poetic language these expressions from the poem $O n$ His Own Life, in spite with the parallels that can be found in Euripidean texts: ex-

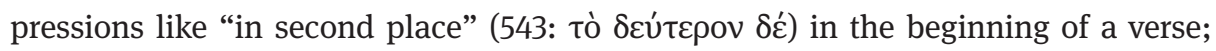

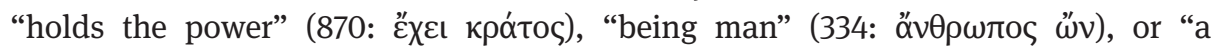

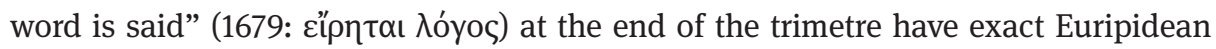
parallels, but nobody would recall them. ${ }^{41}$

Indeed, in comparison to the elevate language of Aeschylus or Sophocles, Euripides was well known by having debased tragic register to almost conversational levels, in which there was little left of poetic language - which gained him both mockery and praise by critics. ${ }^{42}$ This may be a reason for the more frequent presence of his expressions in Gregory's verses, for the Cappadocian poet combines elevate and colloquial registers, and especially in the long poems, his style is quite simple. Furthermore, he systematically avoids imitating Attic tragic language in his iambic trimeters when it implies archaisms, e.g. the Ionian dative plurals in -oisi or forms like mounos instead of monos (instead, he does use these archaisms in his hexameters). ${ }^{43}$

Euripides, therefore, either as a specific referent or as a model for a combination of elevate tragic style and colloquial register, is a clear poetic model for Gregory of Nazianzus when he aspires to compose in iambic trimeters. The imitation of his style is a very efficient mechanism to achieve the ideological neutralization of the tragic register in specific poems - of course those that are adequate to it in meter and in contents. An eloquent example is the tale of Gregory's risky navigation from Alexandria to Athens in his youth, which impressed him so much that he tells it in three texts, in prose, hexameters and iambic verses. ${ }^{44}$ Each has very different vocabulary and style, and each contributes, in its own genre, to neutralize these three traditional Greek styles so that they cease to belong exclusively to 'pagan' literature.

\section{Tragic Myths}

A second level of reception of tragedy refers to the mythical plots whose main source of transmission is tragedy, and in a way they are recognized as "tragic myths". Here, one must again make the distinction between a myth that though treated by Euripi-

40 See Prudhomme 2006, 104, 221.

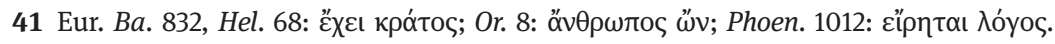

42 Mockery: Ar. Ra. 943-979; praise: Ps-Long. Subl. 40,3; Arist. Rhet. 3,2,1404b18-25.

43 See Prudhomme 2006, 108-109.

44 Prose: or. 18,11; hexameters: On events of his own life (2,1,1), 308-321; iambi: On his own life (2,1,11), 121-210. See Prudhomme 2006. 
des might not be recognized as springing from a particular Euripidean tragedy, e.g. Hecuba, Electra or Oedipus, and those myths in which the impact of Euripidean versions was so important that his tragedies are the direct reference point, e.g. Iphigenia, Medea or Bacchae.

An aforementioned instance is the explicit reference to "seeing two suns" (On His Own Life 562-563), which clearly refers to the Bacchae. Likewise, when he asks "now

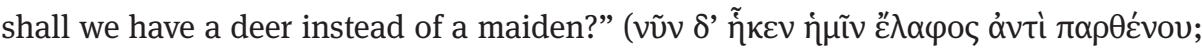
863 ) it is impossible not to think of the myth of Iphigenia precisely in the version famously transmitted by Euripides. ${ }^{45}$

How can such references to myth be interpreted? Contrary to the verbal and stylistic level, the mythical allusions are not so easy to neutralize ideologically. Pagan myth had been used in the apologetic tradition most often as paradigm of inordinate passions and murderous violence, and its appearances in Gregory's poetry are often indebted to earlier Christian literature. For instance, the last part of the poem On Virtue (carm. 1,2,10, 837-872) ends up in a recollection of Zeus' adulterous metamorphoses and other episodes taken up from works like Clement of Alexandria's Protrepticus. $^{46}$ And even in the cases in which the mythical allusion is an ornamental reference or a positive paradigm, many precautions are taken to justify such particular use as an exception that does not diminish the general condemnation of Greek myths, both divine and heroic. Precisely in the last part of this poem, before launching his attach on Greek gods, he mentions some positive exempla of Greek heroes, which he justifies as an exception (825-828): "these are in no way close to my own instances, but I praise them anyway; why so? they are like a white sheep among the Ethiopians (how delightful!) or a freshwater flow in the middle of the sea! Thus too to find among shameful and bad instructions an example of self-control is the greatest wonder!" 47

Among these myths paradigmatic of pagan virtue, some are specifically associated with the realm of tragedy; among prominent examples of Greek heroism he points out to Menoeceus' sacrifice in Euripides' Phoenissae: ${ }^{48}$

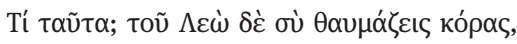

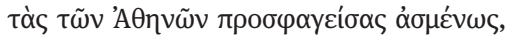

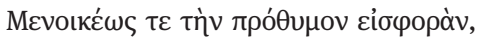

45 See Demoen 1996, 112.

46 Cf. Clem. Al. Protr. 2,14,2; 4,53,4-5 (Crimi and Kertsch 1995, 352-353). For these apologetic topoi, see Herrero de Jáuregui 2010, 219-295.

47 Cf. Demoen 1996, 102 (his translation); on p. 122-123 he explains an analogous passage in the poem Against Women who use Cosmetics (1,2,29), 123-128: "of course I do not attach credence to myths; but if still you insist: see to it that you do not become an exquisite Pandora [...] another story is no longer a myth; listen to my words, which I will tell you from the most divine texts". See Knecht 1972 for a detailed commentary of the passage, which Kannicht in his apparatus links to fr. 429.

48 See Crimi and Kertsch 1995, 322. 


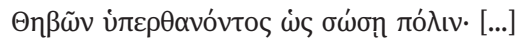

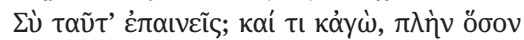

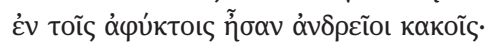

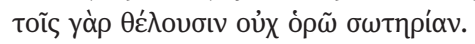

Why these things? You admire the daughters of Leo, voluntarily sacrificing for Athens, and the willing offer of Meneceus to die for Thebes, so that he could save the city [...: praises of Cleombrotus, Epictetus, Anaxarchus and Socrates] - do you praise these things? Me too, somehow, but so much as they were courageous in evils that could not be avoided! I do not see salvation for them even if they had wanted! (Virt. [1,2,10], 676-679. 694-696)

Even if the Greek heroic or philosophical "martyrs” are courageous, their heroism is limited, for they had no other choice. Instead, he continues, the Christian martyr could easily apostate, for "he is just one syllable far from salvation" (728). The case of desperation vs. real martyrdom is symptomatic of the general attitude towards Greek myths, including those from tragedy, which can be used as exempla, but taking into account their general inferiority towards Christianity.

There are also, however, some other passages which announce already the transition to the desecrated, literary myth of the Middle Ages, as Demoen points out: "Gregory treats mythology as a part of religious paganism. Yet, precisely because he denies it the slightest amount of value, as he considers myths sheer fables, he reduces mythology to literature, to a component of the cultural Hellenism which also belongs to the Christian inheritance. Only a desecrated myth can be employed in a literary manner in the view of Christians". ${ }^{49}$ Against previous interpretations, Demoen shows that it is not so much a case of Christianization of the myth (which would mean taking it seriously as a lie of the daemons for example) as of its literaturization. The reference to tragic myths in the aforementioned ethopoietic poem To Vitalianus $(2,2,3)$ is a good example of this literary myth which is naturally integrated in a poem in which the opposition against paganism plays no role at all. Ethopoia was, as the Bodmer papyri demonstrate, a rhetorical exercise practiced by pagans and Christians alike. ${ }^{50}$ Euripidean myths (Agave and Pentheus, Medea) function here as cultural background, not as living religion. In these cases, alluding to a mythical paradigm just inserts Christian poetry in the rhetorical tradition that was common to all Greek educated literature.

49 Demoen 1996, 301. That is why in the poem To Nemesius (2,2,7), 240-255 when he speaks of the "most impious poets" he lists Orpheus, Homer, Hesiod, Hermes and the Sybil, as inspired by demons and, if by any chance said anything right, it was due to theft from the Scripture. This is of course an apologetic commonplace, followed by the usual attacks on oracles, cults, and philosophers. But we should mark out that there is no presence of the tragedians among those "religious poets". Tragedies are not considered as religious texts, and therefore are easier to use as pure literature.

50 See p. 370 n. 8 above. On Libanius' Ethopoiia based on Euripidean characters, see Heinz-Günther Nesselrath in this volume, p. 232-237. 


\section{Tragic Themes}

There is still a third level of appropriation of classical poetry which goes beyond the stylistic recycling of expressions or the use of myth as negative or positive paradigm or as a rhetorical adornment. This level is the recuperation by Christian poets of an ideological trend that is already present in a particular Greek author and is profited and inserted into the Christian Weltanschauung. This is particularly so in the case of Euripides, whose tragedies were the most popular among Christians (and also late antique pagans) due to their presentation of gods more concerned with the resolution of human affairs than Aeschylus or Sophocles, or to the inner emotions of his modern characters, more translatable into Christian categories than the more heroic and unilateral heroes of the previous tragedians. This relative proximity of some Euripidean themes to later Christian worries has been a crucial point in some famous modern judgments of the last great tragedian - enough to mention Friedrich Nietzsche's Die Geburt der Tragödie (1872) and the Jesuit Charles Moeller's Sagesse grecque et paradoxe chrétienne (1948), from opposite perspectives. No matter how distorted Euripidean tragedy becomes when Christianized, this is also doubtless the reason that Euripides is by far the Greek poet most appropriated by Christians, more even than Homer: the presence of the Bacchae in the Acts of the Apostles, in Clement's Protrepticus in the $2^{\text {nd }}$ c. AD, and the Christus Patiens in Byzantine times witnesses a consistent interest in this piece that goes far beyond the manipulation of some lines or some scenes: the presentation of Dionysus as a god unrecognized as such in his human appearance, his power over his devotees, his triumph over the theomachoi, and his final acknowledgement as deity must have struck a chord in several Christian minds that reminded them of Jesus Christ, whose parallelisms with Dionysus have been discussed in multiple levels by ancients and moderns. ${ }^{51}$ Not only the Bacchae had such destiny. Alcestis was sometimes taken by Christians as a model of both the vicarious death of Christ and of his resurrection. ${ }^{52}$

Now in Gregory's poetry there are some prominent themes where the tragic tone becomes particularly suitable. His many poems expressing grief over his own disgraces once defunct often appropriate typically tragic expressions of lamentation. ${ }^{53}$ Also, Euripides was criticized already in antiquity for inserting too many gnomai

51 See the chapters of Thomas Schmitz, Francesco Massa and Lena Krauss in this volume.

52 E. g. Epiphan. Anchor. 8,52 mentions Alcestis along with Pelops, Amphiaraos and Castor, as a prove that Greek myths also contemplate resurrection. The presence of the Barcelona Alcestis, whose main source is obviously Euripides' tragedy, in a papyri codex from the Bodmer collection also presenting Christian psalms is perhaps a testimony of the popularity of this tale in Christian circles. For Bremmer 2008, 205-206 Euripides' piece is even a key influence for the crucial concept of vicarious death first in Hellenistic Judaism and then in Christianity (a thesis developed in a lively debate with Versnel).

53 E. g. carm. 2,1,49-53; 2,1,61-66; 2,1,93-99. 
and moral judgments in his tragedy: ${ }^{54}$ a moralizing trend that greatly contributes to making those sententious expressions very quotable by Christians.

However, apart from these quite self-evident themes, in which similarity of contents calls for tragic expressions within Gregory's general literary project of creating a Christian elevate poetry, there are also other themes in which an explicitly tragic register turns to be particularly adequate, and these themes collaborate in the creation of a new kind of character. The tragic hero suffers, doubts, and fights (in vain) against destiny, loading his decision-making with typical expressions of intense emotion. ${ }^{55}$ This hero is now a Christian who defends his faith against the enemies and against the uncertainties of a life full of sin. The pathetic language expressing suffering and doubt comes now from the Christian speaker, who in the poem On His Own Life turns out to be no other than Gregory himself. Among Euripidean parallels in the poem, several expressions depict situations of crisis and salvation, of doubt and despair, typical of the tragic hero: "what is the way out of the disgraces?"

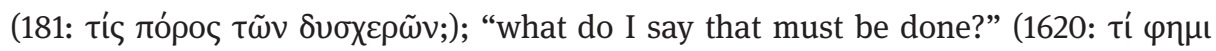

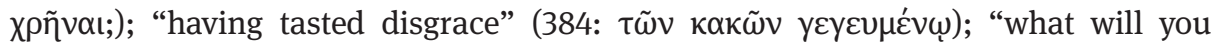

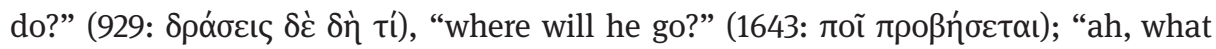

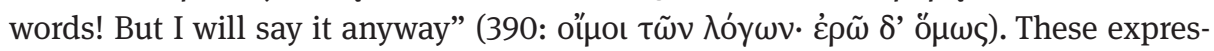
sions have clear parallels in Euripides' plays, and the list could be easily expanded. ${ }^{56}$ Rather than a particularly elevate or tragic style, what they all have in common is that they reflect the critical situations which the tragic hero must confront - and which Gregory will apply to his own autobiographical poem. ${ }^{57}$

That this reshaping of the tragic hero is not only a matter of a single autobiographical poem is shown by the two mentions of the adjective "tragic" in the poems that do not refer to a quotation but as a description. In the poem On Virtue, he says: ${ }^{58}$

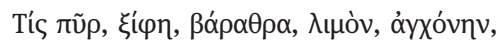

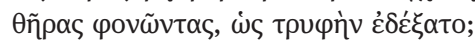

54 E.g. Aeschin. In Tim. 151, 153; Quint. Inst. or. 10,1,68. See Most 2003 on "Euripides ó ү

55 On typical expressions used by doubting tragic heroes, see Rutherford 2012, 295, 316-322.

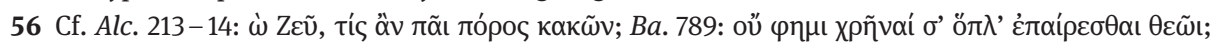

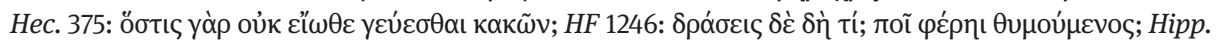

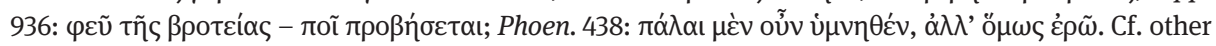

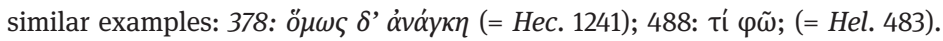

57 Wyss 1983, 846 points out to three "tragic scenes" in the poem: the beginning (lines 51-67) reminds him of a Euripidean prologue; the barroque account of his dangerous trip (128-175); the disappointed lament of $476-485$.

58 Crimi and Kertsch 1995, 329 point out to parallel images in Gregory's discourses talking about martyrdom: or. 25,9-10; 4,79; 8,15. In recent conferences Suzanne Abrams Rebillard has dwelt on Gregory's use of tragic pathos (XVII International Conference on Patristic Studies, Oxford 2015; Annual Meeting of the Society for Classical Studies, New Orleans 2015), although these papers still remain unpublished. 


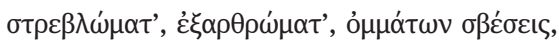

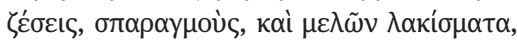

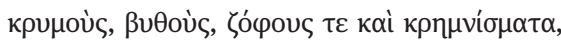

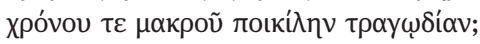

Whoever accepted as a pleasure the fire, swords, abysses, hunger, rope, murderous beasts, tortures, bone breaking, blinding acts, ice, dismemberments and cutting of members, and the varied tragedy of a long time? (carm. 1,2,10, 714-719)

Thus the word "tragedy" summarizes all the tortures and misfortunes that the Christian martyr endures. His suffering, which as we saw is superior to the pagan heroes, is called a "varied tragedy", whose hero is the martyr. It is the Christian version of tragedy, an original response to the typically modern question of whether a Christian tragedy is possible, and which the Christus Patiens will show that offered no doubt for Gregory's later readers who ascribed the play to him.

A slightly different sense is found in another short poem, On Human Life, where he says:

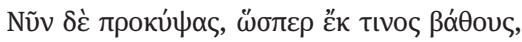

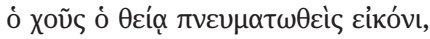

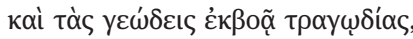

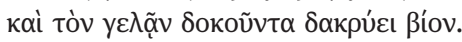

But now, as if falling from some precipice, the dust that received spirit from the divine image, shouts the earthly tragedies and weeps for this life that seems to laugh. (carm. 1,2,18, 12-15)

Here tragedy is equated to suffering and pathos. It is the "earthly tragedy" that is produced by the figures that the dust forms when inspired by the divine spirit. Tragedies weep while life laughs about them. The contrast is clear: the soul on earth is the tragic hero surrounded by enemies.

\section{Conclusion}

Passages similar to the commented verses can be found in Gregory's prose, where for instance tragic language also finds a place in vivid descriptions of martyrdom..$^{59}$ As a rhetorician and as a poet the Cappadocian Father put all his talent and effort into fabricating a Christian literary paideia at a time in which Julian's attempt had made literature a main field of cultural war, and in this enterprise tragedy played a central role. The apologetic tradition defined tragedy as an evil spectacle, which staged scandalous myths and taught inordinate passions. However, in spite of the

59 On theatrical allusions and citations in the Epistles, see Crimi 1981. Cf. McGuckin 2006, who lays out a convincing argument for linking Gregory's poetry and his rhetorical training visible in his prose works. 
heavy presence of such tradition in his poetry, Gregory also worked in the opposite direction, i.e. the integration of the tragic genre in his poetic work: through the neutralization of tragic language, the treatment of myth as literature, and the reshaping of the figure of the tragic hero to depict the Christian man who suffers for justice and God, Gregory's poetry aims to make Christianity as good a participant in Greek classical tradition as his contemporaries of the pagan Third Sophistic. Euripides was a most useful tool in this project, because of his natural language, his didactic trend, and his taste for pathetic parliaments. Perhaps also we may think of a certain implicit fondness of Gregory for him as a character - Gregory's self-centered character as transmitted in his poetry leaves the impression that he might have felt identified as a misunderstood genius who must go to exile because his fellow-citizens treat him unjustly. There are of course significant poetic precedents in the Jewish and Christian tradition for Gregory's enterprise. However, the uncontestable success of his poetic project in the following centuries must also remind us of the importance of his individual talent as an original poet, a learned and creative reader of Euripides, and a renovator of tragic language.

\section{Bibliography:}

Agosti 2005: Gianfranco Agosti, "L'etopea nella poesia greca tardoantica," in: Eugenio Amato and Jacques Schamp (edd.), ETHOPOIIA. La représentation de caractères à l'époque impériale et tardive, Fribourg/Salerno, 34-60.

Azzarà 2003: Silvia Azzarà, “Fonti e rielaborazione poetica nei 'Carmina Moralia' di Gregorio di Nazianzo", in: Maria Serena Funghi (ed.) Aspetti di letteratura gnomica nel mondo antico, Firenze, 53-69.

Basso 2015: Sebastiano Basso, "Per un approccio drammaturgico alle citazioni callimachee in Gregorio di Nazianzo", Atene e Roma 9, 1-24.

Bernardi 2004: Saint Grégoire de Nazianze. Oeuvres Poétiques I. Poèmes Personnels II, 1,1-11. Texte établi par André Tuilier et Guillaume Bady, traduit et annoté par Jean Bernardi, Paris 2004.

Bremmer 2008: Jan N. Bremmer, Greek Religion and Culture, the Bible and the Ancient Near East, Leiden/Boston.

Cataudella 1927: Quintino Cataudella, “Derivazioni da Saffo in Gregorio Nazianzeno”, Bolletino di Filologia Classica 33, 1926/27, 282-284.

Crimi 1981: Carmelo Crimi, Allusioni e citazioni di testi teatrali nell'Epistolario di Gregorio Nazianzeno, Catania.

Crimi 2014: Carmelo Crimi, "Diogene, Pani d'orzo e focacce al sesamo (Gregorio Nazianzeno, Carme I,2,10, 276-281)" in: R. Loredana Cardullo and Daniele Lozzia (edd.) Kallos kai arete. Bellezza e virtù. Studi in onore di Maria Barbanti, Acirale/Roma, 457-466.

Crimi and Kertsch 1995: Carmelo Crimi and Manfred Kertsch, Gregorio Nazianzeno, Sulla virtù carme giambico $(1,2,10)$, Pisa.

Demoen 1996: Kristoff Demoen, Pagan and Biblical Exempla in Gregory Nazianzen. A study in Rhetoric and Hermeneutics, Turnhout.

Easterling and Miles 1999: Pat Easterling and Richard Miles, "Dramatic Identities: Tragedy in Late Antiquity", in: Richard Miles (ed.), Constructing Identities in Late Antiquity, London, 95-111. 
Elm 2012: Susanna Elm, Sons of Hellenism, Fathers of the Church: Emperor Julian, Gregory of Nazianzus, and the Vision of Rome, Berkeley.

Finkelberg 2017: Aryeh Finkelberg, Heraclitus and Thales' Conceptual Scheme: A Historical Study, Boston/Leiden.

Funke 1965/66: Hermann Funke, "Euripides", Jahrbuch für Antike und Christentum 8/9, 233-79.

Herrero de Jáuregui 2010: Miguel Herrero de Jáuregui, Orphism and Christianity in Late Antiquity, Berlin/New York.

Herrero de Jáuregui 2011: Miguel Herrero de Jáuregui, “Christian Assimilation of Pagan Elements: An Apologetic Concept?”, in: David Hernández de la Fuente (ed.), New Perspectives on Late Antiquity, Newcastle, 380-392.

Jungck 1974: Christoph Jungck, Gregor von Nazianz, De vita sua: Einleitung, Text, Übersetzung, Kommentar, Heidelberg.

Kahlos 2012: Maijastina Kahlos, "Pagan-Christian Debates Over The Interpretation Of Texts In Late Antiquity", The Classical World 105, 525-545.

Kambylis 1982: Athanasios Kambylis, "Gregor von Nazianz und Kallimachos”, Hermes 110, $120-122$.

Knecht 1972: Andreas Knecht, Gregor von Nazianz, Gegen die Putzsucht der Frauen: Griech. Text mit Übersetzung, motivgeschichtlichem Überblick und Kommentar, Heidelberg.

Koster 1964: Willem J. W. Koster, "Sappho apud Gregorium Nazianzenum", Mnemosyne 17, 374.

Milovanovic-Barham 1997: Celica Milovanovic-Barham, "Gregory of Nazianzus: Ars Poetica (In suos versus: Carmen 2.1.39)", Journal of Early Christian Studies 5, 497-510.

McGuckin 2006: John Anthony McGuckin, “Gregory: the Rhetorician as a Poet” in: Jostein Børtnes and Tomas Hägg (edd.), Gregory of Nazianzus: Images and Reflections, Copenhagen, $193-212$.

Moreschini and Sykes 1997: Claudio Moreschini and David A. Sykes, St. Gregory of Nazianzus, Poemata Arcana, Oxford.

Patin 1892: Alois Patin, Heraklitische Beispiele, Neuburg.

Prudhomme 2006: Juliette Prudhomme, L'oeuvre poétique de Grégoire de Nazianze, Lyon (thèse de doctorat).

Prudhomme 2009: Juliette Prudhomme, "La critique des poètes profanes dans la poésie de Grégoire de Nazianze", in: Benjamin Goldlust and François Ploton-Nicollet (edd.), Le païen, le chrétien, le profane : recherches sur l'antiquité tardive, Paris.

Robinson 2011: James M. Robinson, The Story of the Bodmer Papyri: From the First Monastery's Library in Upper Egypt to Geneva and Dublin, Eugene.

Roessli 2014: Jean-Michel Roessli, “Assimilation chrétienne d’éléments païens: Construction apologétique ou réalité culturelle?”, Laval théologique et philosophique 70, 507-516.

Rutherford 2012: Richard B. Rutherford, Greek Tragic Style: Form, Language and Interpretation, Oxford.

Simelidis 2009: Christos Simelidis, Selected Poems of Gregory of Nazianzus: 1.2.17; II.1.10, 19, 32: A Critical Edition with Introduction and Commentary, Göttingen.

Stoppel 1882: Paul Stoppel, Quaestiones de Gregorii Nazianzeni poetarum scenicorum imitatione et arte metrica, Diss. Rostock.

Tringali 2012: Adele Tringali, Gregorio Nazianzeno, carm. II, 2, 3: introduzione, traduzione e commento, PhD thesis, Macerata.

Van der Horst 1978: Pieter Van der Horst, The Sentences of Pseudo-Phocylides. With Introduction and Commentary, Leiden.

Vogt 1994: Ernst Vogt, "Das Mosesdrama des Ezechiel und die attische Tragödie”, in: Anton Bierl and Peter von Moellendorff (edd.), Orchestra: Drama Mythos Bühne, Stuttgart, 151-160. 
Wyss 1949: Bernard Wyss, "Gregor von Nazianz: Ein griechisch-christlicher Dichter des 4. Jahrhunderts", Museum Helveticum 6, 177-210.

Wyss 1983: Bernard Wyss, “Gregor II (Gregor von Nazianz)”, RLAC 12, 193-863. 
